\title{
Teaching NeuroImages: Severe spasms resembling status dystonicus as an unusual presentation of stiff-person syndrome
}

Daniel G. Di Luca, MD, Sagari Bette, MD, Carlos Singer, MD, and Corneliu Luca, MD, PhD

Neurology ${ }^{\circledR}$ 2019;92:e748. doi:10.1212/WNL.0000000000006925

A 20-year-old man presented with frequent episodes of generalized rigidity. He had an 18-month history of painful muscle spasms, diaphoresis, and falls. These episodes were associated with anxiety related to pain and the bizarre, unpredictable nature of the symptoms. The patient was admitted with severe tonic spasm episodes lasting for up to 5 minutes, which were initially thought secondary to status dystonicus (video).

CSF analysis revealed an elevated GAD-65 titer (116) and a diagnosis of stiff-person syndrome was made. ${ }^{1,2}$ The episodes were refractory to pharmacologic therapy, requiring use of paralyzing agents and IV immunoglobulin with marked improvement in his condition. ${ }^{1,2}$

\section{Author contributions}

D.G. Di Luca and S. Bette: review of the literature and drafting the case report. C. Luca: patient consent and video footage. C. Luca and C. Singer: critical review of the manuscript and final approval of the version to be published.

\section{Study funding}

No targeted funding reported.

\section{Disclosure}

The authors report no disclosures relevant to the manuscript. Go to Neurology.org/ $\mathrm{N}$ for full disclosures.

\section{References}

1. Espay AJ, Chen R. Rigidity and spasms from autoimmune encephalomyelopathies: stiff-person syndrome. Muscle Nerve 2006;34: $677-690$.

2. Baizabal-Carvallo JK, Jankovic J. Stiff-person syndrome: insights into a complex autoimmune disorder. J Neurol Neurosurg Psychiatry 2015;86:840-848.
Correspondence

Dr. Di Luca

Daniel.garbindiluc@

jhsmiami.org

\section{MORE ONLINE}

\section{- Video}

$\rightarrow$ Teaching slides

links.lww.com/WNL/

A810

From the Department of Neurology, University of Miami Miller School of Medicine, FL. 


\section{Neurology}

\section{Teaching NeuroImages: Severe spasms resembling status dystonicus as an unusual presentation of stiff-person syndrome}

Daniel G. Di Luca, Sagari Bette, Carlos Singer, et al.

Neurology 2019;92; 748

DOI 10.1212/WNL.0000000000006925

This information is current as of February 11, 2019

\section{Updated Information \&} Services

References

Permissions \& Licensing

Reprints including high resolution figures, can be found at: http://n.neurology.org/content/92/7/e748.full

This article cites 2 articles, 1 of which you can access for free at: http://n.neurology.org/content/92/7/e748.full\#ref-list-1

Information about reproducing this article in parts (figures,tables) or in its entirety can be found online at:

http://www.neurology.org/about/about_the_journal\#permissions

Information about ordering reprints can be found online:

http://n.neurology.org/subscribers/advertise

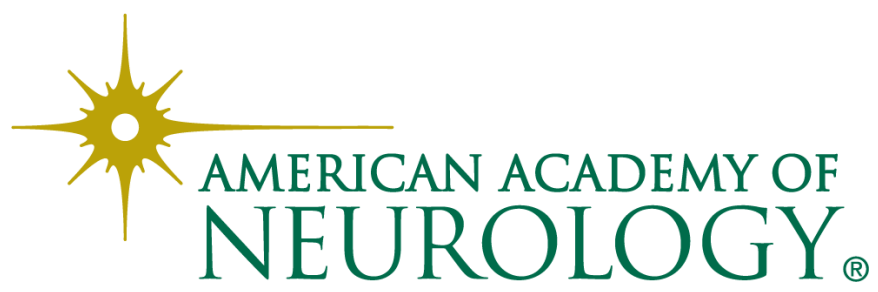

